\title{
From the segregation to the inclusion: Ukrainian realities of the education
}

\begin{abstract}
Alla Kolypayeva, From the segregation to the inclusion: Ukrainian realities of the education [Od segregacji do inkluzji - realia ukraińskiej edukacji]. Interdyscyplinarne Konteksty Pedagogiki Specjalnej, nr 12, Poznań 2016. Pp. 187-194. Adam Mickiewicz University Press. ISSN 2300-391X

Artykuł opisuje strategię ukraińskiej transformacji dotyczącej polityki edukacyjnej w zakresie włączania (inkluzji) - najważniejszej innowacji pedagogicznej XX w. Zauważalne jest, że idea uczenia we wspólnym nurcie nabiera właściwego znaczenia i staje się fundamentalną kategorią dydaktyczną. Wprowadzanie jej w życie ma złożony charakter, wymaga pogłębionego namysłu, rozwoju oraz wdrażania rozwiązań prawnych, programów zawierających treści psychologiczne, pedagogiczne i społeczne.
\end{abstract}

Key words: children with special psychological and physical needs, educational process, inclusion, inclusive education, special education

Today, variative education has become a reality in Ukraine. It is informed by the conceptual framework of "society for all' and "education for all", including for children who until recently were left behind the mainstream education processes due to the then widespread view that considered their education hopeless. Fundamentally, the changes that are happening in Ukraine today as part of education transformation processes represent a real shift from the 
old, reproductive education model, where the mission of the school was to keep the social system unchanged, to a new and dynamic model, where school and education are empowered to develop and upgrade, to reproduce and stimulate social changes. One of the challenges in achieving these objectives is the inability of contemporary schools to respond timely and adequately to the rapid changes in modern education. For example, today the education, in which students are passive receivers of knowledge and do not engage with the community, seems unacceptable. The socialization of children with special educational needs comes to the forefront in the existing special education system; it divides opinion and attracts a lot of criticism.

In Ukraine, notwithstanding its developed and extensive special education system, a significant number of children with disabilities do not have access to special support and have no opportunities to meet their special learning needs.

Built on the tendencies to segregate children with disabilities, the special education system now fails to fully answer the demands of society. There has been a complete mismatch of objectives of the special education system and the value-based objectives declared by society.

Therefore, the issues of their education, development and provision of special support should to be addressed as a matter of urgency.

At present special boarding schools, or internats, where children with disabilities are educated, do not facilitate their social inclusion. While not denying the resource capacities of special boarding schools, the adequate physical environment, high qualification of staff and provision of the required medical, intervention and pedagogical services, it should be noted that such institutions promote segregation and marginalization. At the same time, the advanced education policy sets social inclusion of children with disabilities against segregation and identifies it as a progressive trend for the development of the modern education community.

Nowadays, special education in Ukraine is a system of differentiated educational institutions, both traditional and innovative ones 
(the latter include rehabilitation, recreational, social-medical-pedagogical centers, etc.). Without dwelling on the detailed analysis of the special education system, it is useful to mention that in our country special settings for children with disabilities are subordinated to different government agencies. The Ministry of Education and Science oversees special preschools and schools, psychological, medical and pedagogical centres as well as education and rehabilitation centres. The Ministry of Health is responsible for health centres, early intervention centres, and infant homes. Children's orphanages, social and pedagogical rehabilitation centres, special infant homes etc. fall into the remit of the Ministry of Social Policy and the Ministry of Family, Youth and Sports. The fact that different special institutions for children with disabilities belong to the competence of different agencies creates a host of challenges, because interdepartmental barriers impede full statistical accounting of such children and hinder the efforts to mainstream social and pedagogical support and assistance.

Alongside clear strengths of the contemporary special education system, it is important to point out its significant disadvantages as listed below.

- Its unified nature renders it impossible to meet the needs of all students with disabilities, complicates the introduction of syllabi with multiple instructional options as well as necessary changes and additions to curricula.

- Children with disabilities remain isolated at special boarding schools, which today are the main special educational settings. This creates significant negative implications in social domain, specifically, families do not feel a part of the educational process, students have little opportunities to develop basic social skills and life competencies, etc.

- Social and practical aspects of the educational process are not given sufficient attention, which leads to low levels of social and life competencies in students, little knowledge of social norms and rules and underpin, and a lack of independent living skills. 
- Little individualization and the lack of student-centered approach in teaching and learning create challenges in the emotional and personal development of students, their inadequate assessment of own strengths and abilities.

- Low effectiveness of intervention sessions results in poor communicative competence and social withdrawal.

- The lack of licensed psychological and pedagogical tools to diagnose impairments impedes both proper special preschool/school placement and the organization of the relevant teaching and learning.

- The existing research-based, methodological and teaching resources are not enough to educate children with severe disabilities, atypical impairments, who need additional educational, intervention and rehabilitation services.

At the present stage, the logic of the development of education, including special education, does not harmonize with the logic of society development. This could be explained by the fact that the crisis that the special education system is undergoing due to a critical review of its traditional underlying values, difficulties with material provision for special preschools/schools and a time gap between the level special educational support and the changing social needs.

The objectives to reorganize and upgrade the national teacher training system based on the principles of democracy, humanism, modernization and the recognition of each child's right to education, appropriate to his or her cognitive abilities and the imperatives of our times, serve as reference guides in seeking the best ways to reform it, promote social inclusion of children with disabilities and their integration into the community. Generally, it is assumed that the reorganization of education will be facilitated by inclusive education, the fundamental concept of which reflects one of the key democratic ideas, i.e. all children are valued and active members of the community. Education in inclusive settings is beneficial for children with special educational needs as well as for other children and society as a whole. 
Inclusive education as a set of educational services should be provided by inclusive schools - educational settings that adapt syllabi, curricula and physical environment, make use of the available community resources, engage with parents and collaborate with professionals to provide special services based on the needs of each individual child, as well as ensure a supportive climate at the educational environment.

In post-Soviet counties inclusive processes in the education of children with special needs are characterized by certain distinctive features and have been developing in a particular social and cultural context. Consequently, in Ukraine inclusive education requires a thoughtful approach both on the part of governmental agencies and public, that would take into account the strengths and achievements of educating separate disability-based groups.

In our country the integration of children with disabilities into mainstream education environment as one of the ways to make the entire education system more humanistic, corresponds to the national policy priorities set out in the National Doctrine for the Development of Education in Ukraine for 21st century and include 'student-centred approach to education; creating equal opportunities for children and youth to receive quality education; ensuring multiple options of basic and complete secondary education consistent with individual abilities and capabilities' (National Doctrine of the Development of Education in Ukraine for the $21^{\text {st }}$ century, 2004).

In Ukraine the academic community views the inclusive approach to the education of children with disabilities in terms of its prospects and opportunities to further develop the entire education system. In real time and space, this process is gaining specific features and forms in individual communities, countries and regions, and at the same time it has a universal humanitarian origin and direction.

It should be noted, that inclusive teaching and learning are based on systemic, comprehensive and student-centred approaches and focus on the structural, functional and social dimensions of education. So, to make such teaching and learning successful, 
a supportive social environment needs to be created to nurture the development of children with disabilities and ensure their equal rights to receive educational services. Inclusive education, as a natural and logical transformation of mainstream and special education settings, is one of the core institutes of social inclusion. The implementation of educational integration technologies will help to reconcile the contradictions between the equal rights of persons with disabilities in choosing their life paths, education options, educational services and the actual inequality of opportunity faced by different social groups.

In general, to develop the practices of social inclusion of children with disabilities, it is necessary to transform the national social policy in line with the principles of unconditionally recognizing their rights and freedoms, establishing comprehensive supports and advocating their inclusion into community. This calls for focused and systematic effort to overcome the existing social and cultural ignoring of people with disabilities and negative attitudes towards them.

In this respect a number of conditions may be identified that are key to successful inclusive processes:

- stable national social policy indented to engage all members of society without any exceptions;

- early intervention practices and developmental activities;

- social support and assistance to families of children with disabilities;

- limiting the practice of placing children with disabilities to and educating them at segregated settings;

- developing legal framework for inclusive education of persons with disabilities;

- creating and extending the system of education and vocational training and integrating persons with disabilities into state and non-governmental structures;

- fostering tolerant attitudes towards persons with disabilities.

Tolerance is directly linked to the level of awareness about the development of such people and the specific aspects of their life. 
Based on the above, a number of issues may be formulated by way of recommendations to improve the process of including this group of students into mainstream educational space.

- The effectiveness of inclusive teaching and learning may be enhanced significantly through timely and skilled assessment of the child's development, and though advice and information support provided to teachers and administration of the child's school and to his/her parents.

- Inclusive education of children with disabilities requires inputs by different professionals (e.g. teacher assistant, psychologist, medical worker, social educator and others).

- In the context of educational integration, it is essential organize psychological and pedagogical support for students based on a multidisciplinary approach.

- Support from outside professionals from different settings and organizations should be coordinated at the local level.

- Inclusive education calls for the relevant regulatory legal framework that stipulates legal principles for providing access to different education formats for persons with disabilities.

- It is necessary to design and further improve special education curricula, syllabi, textbooks, teaching and learning aids taking into consideration student-centred and learning-by-doing approaches in educating children with special needs.

- Effective inclusive education depends on special training and re-training for teachers. The purpose of such training will be to help regular school (preschool) educators master the skills for differentiated instruction, using differentiated learning strategies, etc.

Certainly, the introduction of inclusive education requires coordinated and urgent action on the part of the Ministry of Education and Science, Ministry of Health, Ministry of Labour and Social Policy; support from professional associations of teachers, therapists; active involvement of local communities and non-governmental organizations; collaboration with international community that advocates democratic values and principles of civic society. 


\section{References}

Andrews J., Lupart J. (2000) The Inclusive Classroom. Educating Exceptional Children. The University of Calgary: Nelson Thomson Learning

Armstrong F., Armstrong D., Barton L., (Eds.) (2000) Inclusive Education: Policy, Context and Comparative Perspectives. London.

Deppeler J., Loreman T., \& Sharma U. (2005). Reconceptualising specialist support services in inclusive classrooms, Australasian Journal of Special Education, 29 (2). 117-127.

Natsionalna doktryna rozvytku osvity v Ukraini u XXI stolitti [National Doctrine of the Development of Education in Ukraine for the 21 ${ }^{\text {st }}$ century] (2004). Osvita Ukrainy [Ukrainian Education], 5, p. 5

The Salamanca Statement and Framework for Action on Special Needs Education adopted by the World Conference on Special Needs Education: Access and Quality, Salamanca, Spain, 7-10 June 1994 [Ukrainian translation] (2000). Kyiv

United Nations Children's Fund (UNICEF) (2005), Children and Disability in Transition in CEE/CIS and Baltic States. 